University of Pennsylvania Carey Law School

Penn Law: Legal Scholarship Repository

Faculty Scholarship at Penn Law

2004

\title{
The Psychology of Hindsight and After-the-Fact Review of Ineffective Assistance of Counsel
}

\author{
Stephanos Bibas \\ University of Pennsylvania Carey Law School
}

Follow this and additional works at: https://scholarship.law.upenn.edu/faculty_scholarship

Part of the Courts Commons, Criminal Law Commons, Criminal Procedure Commons, Criminology Commons, Criminology and Criminal Justice Commons, Law and Society Commons, Legal Profession

Commons, Psychology Commons, and the Social Control, Law, Crime, and Deviance Commons

\section{Repository Citation}

Bibas, Stephanos, "The Psychology of Hindsight and After-the-Fact Review of Ineffective Assistance of Counsel" (2004). Faculty Scholarship at Penn Law. 935.

https://scholarship.law.upenn.edu/faculty_scholarship/935

This Response or Comment is brought to you for free and open access by Penn Law: Legal Scholarship Repository. It has been accepted for inclusion in Faculty Scholarship at Penn Law by an authorized administrator of Penn Law: Legal Scholarship Repository. For more information, please contact PennlawIR@law.upenn.edu. 


\section{The Psychology of Hindsight and After-the-Fact Review of Ineffective Assistance of Counsel}

Stephanos Bibas ${ }^{*}$

\section{INTRODUCTION}

The Sixth Amendment guarantees criminal defendants effective assistance of counsel. The criminal justice system implements this guarantee by appointing counsel for indigent defendants and then reviewing their performance after the fact, on appeal or habeas corpus. Strickland $v$. Washington's two-pronged test of effectiveness asks first whether defense counsel's "performance fell below an objective standard of reasonableness.". Second, Strickland requires affirmative proof that an error was prejudicial. ${ }^{2}$ This prong requires defendants to prove a reasonable probability that the error affected the outcome of the trial or penalty hearing. ${ }^{3}$

Strickland review is an effort to catch individual errors in individual cases after the fact. According to Strickland, the Sixth Amendment's purpose is "not to improve the quality of legal representation ... [but] simply to ensure that criminal defendants receive a fair trial." ${ }^{4}$ But does this after-the-fact, case-bycase evaluation work? The evidence is not encouraging. Courts rarely reverse convictions for ineffective assistance of counsel, even if the defendant's lawyer was asleep, drunk, unprepared, or unknowledgeable. ${ }^{5}$ In short, any "lawyer with a pulse will be deemed effective. ${ }^{.6}$

*Associate Professor, University of Iowa College of Law; former Assistant U.S. Attorney, U.S. Attorney's Office for the Southern District of New York. E-mail: bibas@philo.org. B.A., Columbia; B.A., M.A., Oxford; J.D., Yale. This essay was originally presented as part of a symposium on criminal procedure at the Washington and Lee University Law School. I am grateful to Frank Bowman, Marc Miller, and Tung Yin for their advice and thoughts on this topic.

${ }^{1} 466$ U.S. $668,688-89$ (1984).

${ }^{2} I d$. at 692 .

${ }^{3} I d$. at $693-95$. The Court was willing to presume prejudice in narrow categories of cases, such as actual or constructive denial of counsel altogether or counsel laboring under actual conflicts of interest. Id. at 692 (citing United States v. Cronic, 466 U.S. 648, 659 (1984); Cuyler v. Sullivan, 446 U.S. 335, 345-50 (1980)).

${ }^{4} I d$. at 689.

${ }^{5}$ Marc L. Miller, Wise Masters, 51 Stan L. Rev. 1751, 1786-87 \& nn.165-70 (1999) (reviewing Malcolm M. Feeley \& Edward L. Rubin, Judicial Policy Making and the Modern State: How the Courts Reformed America's Prisons (1998)); see also Jeffrey L. Kirchmeier, Drink, Drugs, and Drowsiness: The Constitutional Right to Effective Assistance of Counsel and the Strickland Prejudice Requirement, 75 NEB. L. REv. 425, 426-27 (1996) (discussing instances of defense attorneys who were on drugs or slept through trial and were not found incompetent). One article studied about 4000 state and federal appellate decisions and discovered that courts found ineffective assistance in only about 3.9\% of cases. Richard Klein, The Emperor Gideon Has No Clothes: The Empty Promise of the Constitutional Right to Effective Assistance of Counsel, 13 Hastings CONST. L.Q. 625, 632 (1986). Though this study predated Strickland, the rubber-stamp affirmance of convictions persists even after Strickland. 
Why does Strickland have no teeth? One possibility is that judges may consciously avoid the expense and difficulty of reopening and retrying many final convictions. But another possibility is that the very enterprise of after-thefact review is doomed to failure. Judges simply cannot see the errors because psychological biases make it hard to imagine that cases could have come out any differently. This will be particularly true where the defendant has pleaded guilty and there is no trial record to review. Strickland takes pains to guard against one form of hindsight (Monday-morning quarterbacking) but not against the dangerous perception of inevitability. Part II of this article discusses these psychological biases, how they skew appellate and habeas review, and whether judges can guard against them. If after-the-fact review is not the answer, then perhaps we should focus on making prospective improvements in the quality of counsel. Part III discusses how and why these insights should spur legislatures and judges to move beyond complacent reliance on Strickland to take more active measures.

\section{HINDSIGHT BIAS AND INEVITABILITY}

Psychologists have repeatedly found that, in hindsight, people tend to think the eventual outcome was inevitable all along. For example, one study asked physicians to diagnose the illnesses of patients with various symptoms who had since passed away. One group of physicians received autopsy reports that listed the actual causes of death; the other group did not receive the autopsy reports. All of the physicians then wrote down what probabilities they would have assigned to various diagnoses if they had been the treating physicians. Those who had seen the autopsy reports were asked to disregard the reports in gauging the probabilities. Nevertheless, those who had seen the autopsy reports rated the autopsy diagnoses as more probable than did those who never saw the reports. ${ }^{7}$

Hindsight could, in theory, cut in two directions. One possibility is that reviewing courts could revisit all of defense counsel's tactical decisions, imagining how the case might possibly have come out differently. This is what

See Stephen Bright, Counsel for the Poor: The Death Sentence Not for the Worst Crime But for the Worst Lawyer, 103 YALE L.J. 1835, 1862 (1994) ("Together, the lax standard of Strickland and the strict procedural default doctrines reward the provision of deficient representation.").

${ }^{6}$ Miller, supra note 5, at 1786.

${ }^{7}$ N.V. Dawson et al., Hindsight Bias: An Impediment to Accurate Probability Estimation in Clinicopathologic Conferences, 8 MED. DeCISION MAKING 259, 260-61 (1988). More than a hundred other studies have replicated the same finding in other contexts. See Jay J. ChristensenSzalanski \& Cynthia Fobian Willham, The Hindsight Bias: A Meta-Analysis, 48 OrG. BEHAV. \& Hum. DeCision Processes 147, 150 (1991) (finding 122 studies demonstrating presence of hindsight bias); Scott A. Hawkins \& Reid Hastie, Hindsight: Biased Judgments of Past Events After the Outcomes are Known, 107 PsYCHOL. Bull. 311, 312-16 (providing examples of various studies showing effects of hindsight bias on judgment). 
we call Monday-morning quarterbacking, 20/20 hindsight, or outcome bias. ${ }^{8}$ An example might be second-guessing a defense attorney's advice that the defendant testify because, as it turned out, the prosecutor's cross-examination was devastating. Defense counsel may take a calculated gamble and lose, but in hindsight this calculated gamble may look like an error. This bias affects the first prong of Strickland, the deficiency of counsel's performance.

A contrary possibility is that, looking back at a final result, courts might regard that outcome as inevitable. ${ }^{9}$ This assumption of inevitability is related to another psychological bias: people tend to interpret new evidence so as to confirm their initial judgments. This is sometimes called the confirmatory bias. ${ }^{10}$ Assume, for example, that reviewing courts subconsciously assume that the defendant is guilty and probably would have been convicted anyway because most defendants are convicted. If so, these courts might discount alleged attorney errors, regarding them as tactical decisions or irrelevant to the foreordained outcome. These biases are more likely to affect Strickland's second prong, the effect of the error on the outcome.

Some scholars have assumed that hindsight bias would make reviewing courts too willing to find ineffective assistance of counsel. ${ }^{11}$ But the evidence discussed above suggests that, on the contrary, judges are loath to reverse despite blatant errors. Why? One reason is that Strickland requires defendants to satisfy both prongs. Even if Monday-morning quarterbacking helps to satisfy the first prong, the air of inevitability and the confirmatory bias make it hard to satisfy the second.

\footnotetext{
${ }^{8}$ See Jonathan Baron \& John C. Hershey, Outcome Bias in Decision Evaluation, 54 Personality J. \& Soc. Psychol. 569, 569-70 (1988); see also Diane M. Mackie et al., The Impact of Perceiver Attitudes on Outcome-Based Dispositional Inferences, 19 Soc. CoGNITION 71,72 (2001) (reporting that, in study, spectators judged actors' intelligence based on whether actors won or lost game rather than on actors' actual performance).

${ }^{9}$ See supra note 7 and accompanying text; Gordon Wood, The Knew-It-All-Along Effect, 4 J. Experimental Psychol.: Hum. Perception \& Performance 345, 352 (1978) (explaining that "subjects are either unwilling or unable to ignore outcome knowledge, or are unaware of the effect of outcome knowledge"); see also Fred B. Bryant \& Rebecca L. Guilbault, "I Knew It All Along" Eventually: The Development of Hindsight Bias in Reaction to the Clinton Impeachment Verdict, 24 J. BASIC \& APPLIED SOC. PSYCHOL. 27, 37 (2002) (finding that after subjects of study had learned outcome, "they mistakenly came to believe that they had a clearer sense of inevitability from the start"). As historian Georges Florovsky has observed:

The tendency toward determinism is somehow implied in the method of retrospection itself. In retrospect we seem to perceive the logic of the events, which unfold themselves in a regular order, according to a recognizable pattern, with an alleged inner necessity, so that we get the impression that it really could not have happened otherwise.

Georges Florovsky, The Study of the Past, in 2 IDEAS OF History 351, 364 (R.H. Nash ed., 1969).

${ }^{10}$ See Charles G. Lord et al., Biased Assimilation and Attitude Polarization: The Effects of Prior Theories on Subsequently Considered Evidence, 37 J. Personality \& SOC. PsYCHOL. 2098, 2102-08 (1979); S. Plous, Biases in the Assimilation of Technological Breakdowns: Do Accidents Make Us Safer?, 21 J. APPLIED Soc. PSYCHOL. 1058, 1059 (1991).

${ }^{11}$ Chris Guthrie et al., Inside the Judicial Mind, 86 CORNELL L. REv. 777, 800-01 (2001).
} 
A second reason is that most defendants plead guilty. ${ }^{12}$ If a defendant has already admitted guilt, his conviction looks inevitable in hindsight and it is hard to argue innocence later. Even those defendants who are convicted at trial may admit guilt at sentencing, making it harder to then plausibly deny guilt on appeal or habeas.

A third problem is that guilty pleas dispense with trial records, so appellate courts have scant evidence to review in deciding how a case might have come out otherwise. ${ }^{13}$ With little evidence to go on, judges may fall back on their presumption of correctness or inevitability. In other words, defendants cannot shoulder their burden of affirmatively proving prejudice.

Fourth, many defendants raise ineffectiveness claims, regardless of their merit. After all, that is one of the few claims that can be raised in almost every case, as almost every defendant has a lawyer. Courts of appeals, flooded with frivolous ineffectiveness claims, approach each one with a jaundiced eye. As Justice Jackson put it: "It must prejudice the occasional meritorious application to be buried in a flood of worthless ones. He who must search a haystack for a needle is likely to end up with the attitude that the needle is not worth the search." 14

Strickland itself recognized the danger of Monday-morning quarterbacking. The Court's opinion insisted that review be "highly deferential" and "evaluate the conduct from counsel's perspective at the time." 15 Otherwise, "the distorting effects of hindsight" would spawn routine collateral litigation and make defense counsel too fearful of being secondguessed. ${ }^{16}$ But Strickland did not say or do anything to guard against the inevitability and confirmatory biases. Nothing in Strickland cautions judges against assuming that conviction is automatic. If anything, the exhortations to deference and the defendant's burden of proof suggest that, when in doubt, courts should affirm. ${ }^{17}$ Because guilty-plea cases lack well-developed trial

${ }^{12}$ Bureau of Justice Statistics, U.S. Dep'T of Justice, Sourcebook of Criminal JUSTICE StATISTICS 2002, at 416 tbl.5.17, available at http://www.albany.edu/sourcebook (reporting that in fiscal year 2000, of 69,283 criminal cases disposed of in federal district court by trial or plea (thus excluding dismissals), 64,939 (93.7\%) were disposed of by pleas of guilty or nolo contendere); id at 448 tbl.5.46 (reporting that in 2000, of about 924,700 felony convictions in state court, about 879,200 (95\%) were by guilty plea).

${ }^{13}$ Perhaps in a few cases it will be clear that defense counsel could have brought a motion to suppress that would have resulted in dismissal rather than a plea bargain, but rarely will the record be so clear-cut.

${ }^{14}$ Brown v. Allen, 344 U.S. 443, 537 (1953) (Jackson, J., concurring in result).

${ }^{15}$ Strickland v. Washington, 466 U.S. 668, 689 (1984).

${ }^{16}$ See id. at $689-90$ (noting that "intrusive post-trial inquiry" would "encourage the proliferation of ineffectiveness challenges" and would harm defense counsel's performance and willingness to serve, dampen his ardor, impair his independence, and undermine trust between attorney and client).

${ }^{17} \mathrm{See}$ id. at 689 (noting that because of difficulties involved in evaluating attorney performance, courts must strongly presume that "counsel's conduct falls within the wide range or reasonable professional assistance..."). 
records, appellate judges may often be in doubt and fall back on this deference.

Perhaps courts could do more to guard against the inevitability bias. Unfortunately, merely telling someone about a cognitive bias or asking her to try harder is ineffective to correct that bias. ${ }^{18}$ Nor does practice make perfect. Studies find that experience and expertise may moderate, but do not eliminate, cognitive biases. ${ }^{19}$ A more successful tactic is to ask subjects to consider the opposite and articulate reasons why the case could have come out otherwise. ${ }^{20}$ Defense lawyers are supposed to help appellate judges see the other side, but poor appellate counsel or pro se habeas petitions may not succeed in doing so.

Another possible approach to hindsight review would be to establish clear benchmarks, guideposts, or checklists. If, for example, Strickland required defense counsel to interview all known eyewitnesses to a crime, assessing compliance would be more objective and less susceptible to bias. Strickland, however, refused to define what conduct was unreasonable, declaring: "More specific guidelines are not appropriate. ${ }^{21}$ Though the Court alluded to American Bar Association standards as guides to what conduct is reasonable, it feared that particular, detailed rules would hamper counsel's flexibility. ${ }^{22}$ Instead, the Court has fallen into the opposite trap of giving courts and counsel no guidance. Deference and the presumption of effectiveness turn flexible review into almost no review at all, as courts can find some rationale for almost any behavior. When courts start out presuming that attorney actions are tactics rather than errors, the confirmatory bias leads them to interpret almost

${ }^{18} \mathrm{See}$ Baruch Fischhoff, Perceived Informativeness of Facts, 3 J. EXPERIMENTAL PSychol.: Hum. Perception \& Performance 349, 356 (1977) (reporting that experiment replicated knew-it-all-along effect and found that "exhorting subjects to work harder or telling them to beware of bias in their responses" did not weaken effect); Richard M. Kurtz \& Sol L. Garfield, Illusory Correlation: A Further Exploration of Chapman's Paradigm, $46 \mathrm{~J}$. CONSUlting \& Clinical PSYCHOL. 1009, 1014 (1978) (finding that training did not reduce associations made based on verbal associative connections rather than on valid observations); Wood, supra note 9, at 345-46.

${ }^{19}$ See Daniel Kahneman \& Amos Tversky, Subjective Probability: A Judgment of Representativeness, in JUdGMENT UNDER UNCERTAINTY: HEURISTICS AND BIASES 32, 32-33 (Daniel Kahneman et al. eds., 1982) [hereinafter JUDGMENT UNDER UNCERTAINTY] (discussing sophistication in statistics as possible corrective to representativeness biases); Amos Tversky \& Daniel Kahneman, Judgments of and by Representativeness, in JUDGMENT UNDER UNCERTAINTY, supra, at 84, 84-85 (same).

${ }^{20}$ See Hal R. Arkes et al., Eliminating the Hindsight Bias, 73 ApPLIED PsyCHOL. 305, 307 (1988) ("Having the diagnostician list or generate reasons why other outcomes might have been expected should heighten appreciation of the difficulty of the case, the plausibility of other diagnoses, and the information value of the correct answer."); Charles G. Lord et al., Considering the Opposite: A Corrective Strategy for Social Judgment, 47 J. PERSONALITY \& SOC. PSYCHOL. 1231, 1239 (1984) ("[T]he cognitive strategy of considering opposite possibilities promoted impartiality.").

${ }^{21} 466$ U.S. at 688; see also id. at 696 ("[A] court should keep in mind that the principles we have stated do not establish mechanical rules.").

${ }^{22} I d$. at $688-89$. 
any action as tactical. This became painfully clear in McFarland v. State, ${ }^{23}$ where the Texas Court of Criminal Appeals reviewed a capital case in which the defense lawyer had napped during trial. ${ }^{24}$ The court found that counsel had not been ineffective, in part because napping might have been a "strategic" move designed to elicit jury sympathy. ${ }^{25}$ If the confirmatory bias is this strong, then Strickland degenerates into a game of concocting hypothetical justifications after the fact. Strickland winds up being almost as toothless as rational-basis review under the Equal Protection Clause, which also rests on post hoc rationalizations instead of actual reasons.

Perhaps asking judges to construct the strongest arguments for the defendant might somewhat moderate the hindsight and confirmatory biases. But I am not optimistic because of the structural problems at work. It is just too hard for judges to screen out the fact of conviction and imagine being in defense counsel's shoes before the fact. This is particularly true because judges have little or no records of out-of-court pretrial and plea-bargaining decisions, apart from the defendant's own incriminating plea. Thus, they will probably over-rely on the presumption that counsel was effective, the verdict was correct, and the plea bargain was sound because the defendant agreed to it.

\section{IMPROVING COUNSEL BEFORE THE FACT}

Strickland rejected detailed guidelines because its aim is "not to improve the quality of legal representation ... . [but] simply to ensure that criminal defendants receive a fair trial. ${ }^{26}$ Because of the psychological and structural difficulties of hindsight review, however, it is hard to ensure fair trials without trying to improve the quality of representation. The two goals are intimately linked. By ensuring justice in particular cases, judicial review should deter errors in future cases. Ideally, there should be a feedback loop, in which the costs of reversals on the back end spur legislators, judges, and counsel to improve the front end. Reversals should also have a psychological and educative effect, serving as precedents and teaching future lawyers what not to do. Defense lawyers are not the only ones who need to learn from reversals. Legislators and the public need to see the problems generated by appointed lawyers' poor salaries, inadequate support, and staggering caseloads. They also should understand that if they leave these problems unaddressed, courts may toss out criminal convictions.

Unfortunately, the feedback loop is broken. Judges almost never reverse convictions for ineffective assistance of counsel. Even if they did, legislatures and the public might not understand the connection between front-end funding

${ }^{23} 928$ S.W.2d 482 (Tex. Crim. App. 1996), overruled on other grounds by Mosley v. State,

983 S.W.2d 249, 263 n.18 (Tex. Crim. App. 1998).

${ }^{24} 928$ S.W. 2 d at 505.

${ }^{25} \mathrm{Id}$. at $505 \& \mathrm{nn} .19,20$.

${ }^{26} 466$ U.S. at 689 . 
of defense counsel and back-end ineffective-assistance claims. The political process rarely sits up and takes notice of what happens after conviction, and the criminal process rarely is transparent enough for outsiders to see the problems. Without some outside pressure, the political process alone rarely will address the problem. The political pressure to be seen as tough on crime usually militates against protecting defendants' rights, discriminating against a classic "discrete and insular minorit[y]."27

In one area, states have tried to improve representation by improving the qualifications of counsel. In capital cases, a majority of the thirty-eight states that authorize the death penalty prescribe minimum qualifications for capital defenders. ${ }^{28}$ These qualifications commonly set minimum levels of experience, number of trials, and training. These provisions are undercut, however, by the lack of any enforcement mechanism or relief for violations. ${ }^{29}$ The reform, while an admirable step, does nothing to relieve the excessive caseloads and paltry compensation that are the root of many problems.

A few courts have tried to use shock therapy to wake up the political branches. State v. Peart ${ }^{30}$ involved the representation of public defender Rick Teissier. $^{31}$ Teissier handled dozens of felony cases at any one time with inadequate investigative, library, and staff support. ${ }^{32}$ The trial court found that Teissier's representation of his entire caseload was ineffective. ${ }^{33}$ It further ruled that the entire system of indigent defense in New Orleans was constitutionally inadequate. ${ }^{34}$ The trial court ordered the legislature to fund more investigators, library materials, defense attorneys, secretaries, paralegals, law clerks, investigators, and expert witnesses. ${ }^{35}$

The Louisiana Supreme Court reversed. ${ }^{36}$ It agreed that the indigent defense system in New Orleans was chronically overburdened and often inadequate. ${ }^{37}$ Nonetheless, it declined to order the expenditure of more funds, at least for the time being. ${ }^{38}$ Separation-of-powers concerns weighed against

${ }^{27}$ This phrase, of course, comes from United States v. Carolene Products Co., 304 U.S. 144, 152 n.4 (1938). See generally John Hart Ely, Democracy and Distrust: A THEORY of JUDICIAL REVIEW 78 (1980) (noting that representatives' desire to be reelected may be the majority's insurance policy, but that this does not ensure "effective protection of minorities whose interests differ from the interests of [the majority]").

${ }^{28}$ Donald J. Hall, Effectiveness of Counsel in Death Penalty Cases, 43 BRANDEIS L.J. (forthcoming 2004) (manuscript at 6, on file with author).

${ }^{29} \mathrm{Id}$. at $12-16$.

${ }^{30} 621$ So. $2 d 780$ (La. 1993). My discussion of Peart and Lynch, infra text accompanying note 50, is indebted to Marc L. Miller, supra note 5, at 1791-1802.

${ }^{31} I d$. at 784 .

${ }^{32} I d$.

${ }^{33} I d$.

${ }^{34} I d$.

${ }^{35} \mathrm{Id}$. at $784-85$.

${ }^{36} I d$. at 783 .

${ }^{37} \mathrm{Id}$. at $783,789-91$.

${ }^{38}$ Id. at 791 . 
such an intrusive remedy. ${ }^{39}$ The court took the less radical step of rebuttably presuming that all indigent defenders in Section E of the New Orleans courts were rendering ineffective assistance. ${ }^{40}$

Even this ruling was quite sweeping and sparked serious change in Louisiana. Shortly before Peart, the Louisiana State Legislature had refused to authorize more funding for indigent defense. ${ }^{41}$ But in the two years following Peart, the Louisiana Legislature increased indigent-defense funding by $\$ 5$ million. ${ }^{42}$ Two years later, the legislature appropriated $\$ 7.5$ million for the Louisiana Indigent Defender Assistance Board. ${ }^{43}$

This clear, high-visibility decision grabbed the legislature's attention in a way that no series of individual reversals could have. Because the court framed its decision as a rule, rather than case-by-case application of a multifactor standard, its decision was more transparent. It thus had more impact on legislation. This kind of proactive move has its dangers, because it stretches the traditional role of the judiciary, which is reacting to individual cases or controversies. ${ }^{44}$ (The concern would have been greater if the courts had gone even further and ordered the legislature to raise taxes or expend specific sums of money on public-defender programs.) But these pronouncements brought systemic improvement in a way that individual reversals could not have, for two reasons. First, they made clear that individual ineffectiveness often stems from systemic failings. Second, they attached palpable consequences to continuation of the flawed status quo. This goad temporarily offset the political dynamic that systematically undervalues defendants' constitutional right to representation.

Unfortunately, this victory was only temporary. Over time, the money failed to keep up with inflation and caseloads, and today New Orleans defense counsel still have heavy caseloads. The judicial ruling acted as a one-time goad, but did not transform the financing and structure that created long-term problems. ${ }^{45}$

Like Louisiana, Oklahoma underwent a system-wide change after the case of State v. Lynch. ${ }^{46}$ In that case, a trial court appointed two lawyers to represent a capital defendant, ${ }^{47}$ who was later convicted and sentenced to life

${ }^{39} \mathrm{Id}$.
${ }^{40} \mathrm{Id}$.
${ }^{41}$ See Lee Hargrave, Ruminations: Mandates in the Louisiana Constitution of 1974; How Did They Fare?, 58 LA. L. REv. 389, 398 n.45 (1998).

${ }^{42}$ Id.

${ }^{43}$ See id.; LA. Rev. StAT. AnN. §§ 15:144 46 (West Supp. 2003).

${ }^{44}$ This might be less of a concern in many states, however, because many state constitutions lack the federal constitution's case-or-controversy requirement. Thus, for example, many state courts feel free to render advisory opinions.

${ }^{45}$ Ronald F. Wright, Parity of Resources for Defense Counsel and the Reach of Public Choice Theory, 90 IOWA L. REv. (forthcoming 2004).

${ }^{46} 796$ P.2d 1150 (Okla. 1990).

${ }^{47} I d$. at 1153 . 
imprisonment. ${ }^{48}$ The appointed lawyers sought reimbursement of their overhead and expenses, which totaled $\$ 17,073$ and $\$ 10,995$, well in excess of the $\$ 3200$ statutory cap. ${ }^{49}$ These claims did not include any additional amount for attorneys' fees or other compensation. ${ }^{50}$

The trial court held the $\$ 3200$ cap unconstitutional, and the Oklahoma Supreme Court affirmed insofar as the cap applied to the case at hand. ${ }^{51}$ The court held that the cap was unconstitutional for three reasons. First, it denied the lawyers a due process opportunity to show cause why they should not be forced to take appointments. ${ }^{52}$ Second, the fee cap effected a taking of their private property without just compensation. ${ }^{53}$ And third, the cap arbitrarily discriminated among lawyers. ${ }^{54}$ Private attorneys in districts with public defenders need not take court appointments, but those in districts without public defenders must do so. ${ }^{55}$

Instead of simply finding the statutory fee inadequate in this particular case and exhorting the Legislature to raise it, the Oklahoma Supreme Court went further. It laid down an interim set of guidelines to govern attorneys' fees until the Legislature took action. ${ }^{56}$ The court set a statewide hourly rate pegged to prosecutors' salaries, stating that defense counsel's salaries deserve parity with prosecutors'. ${ }^{57}$ The court also required reimbursement of overhead expenses, to match the state's provision of overhead for prosecutors. ${ }^{58}$ The court did not go further in dictating the best type of indigent-counsel system or the absolute levels of salaries. ${ }^{59}$

The court's measure was nevertheless drastic enough to spur the state Legislature to action. The next year, the Oklahoma Legislature created a statewide indigent-defender board and substantially raised fee caps for appointed counsel. ${ }^{60}$

Both Peart and Lynch succeeded in prodding legislatures to action. One might have expected that the success of this approach would cause other courts to follow suit. Other courts, however, have declined to make broad rulings that

${ }^{48} I d$.

${ }^{49}$ Id. at $1153-54$.

${ }^{50}$ Id. at 1153 .

${ }^{51} I d$. at 1154 .

${ }^{52} \mathrm{Id}$.

${ }^{53} I d$.

${ }^{54} \mathrm{Id}$. at 1159 .

${ }^{55}$ See id. at $1159-60$.

${ }^{56} I d$. at 1161 .

${ }^{57} I d$.

${ }^{58}$ Id. at $1161-62$.

${ }^{59}$ See Miller, supra note 5, at 1799 .

${ }^{60}$ Id. at 1801 \& nn.255-57 (citing OKLA. STAT. ANN. tit. 22, $\S \S 1355.8,1355.13,1355.14$ (West Supp. 1999)). 
might spark sweeping change, though the cases may have influenced favorable settlements in a few other places. ${ }^{61}$

The moral of the story is that while judges can promote effective assistance of counsel via systemic reform, they are reluctant to flex their muscles. Most judges see this kind of policy making as inappropriate for courts. They agree with Strickland that the goal of judicial review is not to improve counsel systems, but to ensure a fair trial for a particular defendant. This approach, however, assumes that the alternative of hindsight review can ensure fair trials. Where psychological biases obstruct hindsight review, and systemic flaws impede representation, after-the-fact review may be inadequate. We may have no choice but to fix the front end of the system, as back-end review simply does not work.

A Peart-type presumption might work as a stopgap solution. Recall that one psychological problem with Strickland review is the strong presumption of effective assistance, which buttresses the inevitability bias. If instead judges presume that counsel was ineffective, perhaps they will be less willing to affirm automatically. In those areas of uncertainty, such as where the record is undeveloped before a guilty plea, they may lean towards defendants. After all, presumptions carry weight where a court is uncertain which side should prevail. One hitch here is that the Peart presumption might make judges more willing to find ineffectiveness on Strickland's first prong, but the inevitability bias might still prevent reversal under the second prong. The other problem is that reversal of convictions is such a drastic remedy that judges may be too reluctant to impose it in cases of uncertainty. Further, if the remedy is simply another prosecution under the same flawed system, reversal may seem like a waste of resources. But at least at the margins, one might expect this presumption to counteract these biases and spur some change.

Peart's solution is a temporary one, as one-time funding inçreases will not transform a system. The Lynch approach is more promising because it rests on the attractive principle of parity. As Ron Wright has argued, there is much intuitive appeal to the idea of giving resource parity to prosecutors and public defenders. ${ }^{62}$ At the very least, this means paying them comparable salaries; ideally, it would also include some parity of caseloads and support services, though these are harder to commensurate. ${ }^{63}$ The beauty of this principle is that it recasts funding decisions not as helping criminals, but as putting each side on a level playing field. Thus, many states already have some legislation embodying parity of salaries, and a few have experimented with broader

${ }^{61}$ See id. at 1801-03 (discussing Mississippi and Minnesota case law declining to follow Peart and Lynch); Wright, supra note 45, at 22-23 ("Most often, courts still dispose of defendants' claims based on inadequate funding by applying the Strickland standard.").

${ }^{62}$ Wright, supra note 45 , at 5 ("Resource parity builds on a venerable idea; the defense function is just as important to society as the prosecutorial function.").

${ }^{63} I d$. at $11-19$. 
notions of parity. ${ }^{64}$ Maybe, just maybe, the judicial efforts to achieve parity can encourage legislatures to reframe the question this way and peg defense resources to prosecutorial or judicial resources, to inflation, and to caseload increases. These funding hikes could be automatic, much as cost-of-living increases automatically raise Social Security payments to keep pace with inflation. Ultimately, these systemic changes can take root only if legislatures will write these principles of fairness into law. ${ }^{65}$ Given the politics of being tough on crime, this outcome is uncertain at best.

\section{CONCLUSION}

Courts face an uncomfortable choice. On the one hand, traditional Strickland review has no teeth because the strong presumption of effectiveness and the inevitability hindsight bias cloud case-by-case, post-hoc review. One could tinker with Strickland by establishing concrete requirements or checklists for effective assistance, or by weakening or even reversing the presumption of effectiveness. These measures, while improvements, are modest at best. Hindsight biases and scanty records create grave problems for after-the-fact review, problems that are easy to lament but hard to fix.

On the other hand, courts can try to spur legislative reforms through aggressive rulings that affect many cases. An extreme approach would involve judicial takeovers of public-defender systems, complete with orders to raise taxes and expend large sums of money. This approach runs up against the separation of powers, as broader solutions stretch well beyond a particular case or controversy. Yet if courts limit their scope to individual cases, their lowprofile rulings will go unnoticed and unheeded. It may be possible to steer a middle course between wholesale legislation and traditional case-by-case adjudication. The Peart and Lynch decisions used traditional tools, such as evidentiary presumptions and fee awards, in novel ways to send messages. Even this remedial creativity, it seems, is too radical for most courts, as few have followed these leads.

In theory, ex post review should create ex ante incentives to provide competent counsel. In practice, the system does not work that way, as there is no good feedback loop to prod legislatures into action. The moral of the story echoes one of Bill Stuntz's themes: courts create constitutional procedural rights, but legislative underfunding undercuts these guarantees in practice. ${ }^{66}$ Perhaps the best that courts can do is to use publicity and clear rulings to draw attention to this dynamic, underscoring the need for legislative change to avert possibly drastic judicial measures.

\footnotetext{
${ }^{64} I d$.

${ }^{65} I d$. at $28-38$.

${ }^{66}$ See William H. Stuntz, The Uneasy Relationship Between Criminal Procedure and Criminal Justice, 107 YALE L.J. 1, 6-7, 65-67 (1997).
} 